\title{
STUDI SOSIO RELIGI WISATA ALAS KETONGGO DESA BABADAN KECAMATAN PARON KABUPATEN NGAWI
}

\author{
Anis Nuryani \& Muhammad Hanif*
}

\begin{abstract}
Abstrak
Penelitian ini bertujuan untuk mengetahui dampak wisata terhadap kehidupan sosio religi masyarakat Desa Babadan. Penelitian ini diadakan di Desa Babadan Kecamatan Paron Kabupaten Ngawi. Tepatnya objek penelitian ini berada di Dusun Nanggalan Rt. 10 Rw.02 di area perhutani RKPH Kuncen Babadan.

Penelitian ini merupakan penelitian kualitatif. Jenis penelitian yang digunakan yaitu jenis penelitian studi kasus. Teknik pengambilan data yaitu wawancara, observasi, dan dokumentasi. Teknik pengumpulan sampel dengan purposive sampling. Sumber data yang dipakai yakni sumber data primer dan sumber data sekunder. Teknik keabsahan data yang digunakan untuk menguji kebenaran data yaitu trianggulasi sumber. Analisis data yang digunakan adalah analisis data model interaktif Miles dan Huberman.

Hasil penelitian menunjukkan bahwa kunjungan wisata ke Alas Ketonggo merupakan tradisi turun temuru dan sudah berakar kuat di kalangan masyarakat Jawa. Meskipun muncul kritik yang mencurigai praktek semacam itu dapat menodai tauhid ajaran agama, tetapi dalam faktanya kegiatan mengunjungi wisata religi tidak pernah pudar sama sekali bahkan cenderung makin ramai terutama setelah terbukti makin keramatnya wisata religi ini. Kepercayaan pengunjung memang mengkeramatkan beberapa tempat di Alas Ketonggo tersebut. Meskipun demikian, kepercayaan tersebut tidaklah tunggal karena sangat tergantung pada pola pikir, pemahaman keagamaan dan tradisi yang melingkupinya. Penelitian ini sampai pada kesimpulan adanya kepercayaan yang berbasis pada pola tradisional Islam, kepercayaan mistis yang berbasis pada tradisi, dan kepercayaan yang berdasar pada pemikiran-rasional belaka yang di yakini oleh masyarakat Desa Babadan dan para pengunjung.
\end{abstract}

Kata kunci : Sosio Religi, Wisata

\section{Pendahuluan}

Indonesia adalah salah satu negara kepulauan, dengan beragam budaya serta suku bangsa. Dari Sabang sampai Merauke, suku bangsa Indonesia memiliki ciri khas berbedabeda. Ciri khas ini disebabkan oleh banyak hal, yakni keadaan geografis, sistem sosial, dan sistem keagamaan. Hal itu dapat mempengaruhi dan membentuk watak, perilaku, maupun pola pikir masyarakat. Ciri khas tersebut merupakan suatu nilai positif yang dimiliki bangsa Indonesia dalam hal keanekaragaman budaya. 
Salah satunya adalah budaya Jawa, orang Jawa dikenal ramah, terbuka, sopan dan religius, ada bermacam agama dan kepercayaan yang sempat dianut oleh orang Jawa dan berpengaruh besar terhadap budaya dan pandangan hidupnya. Yaitu, kepercayaan pra-Hindu: animisme dan dinamisme, kemudian Hindu, Budha dan Islam (Imam Budhi Santosa, 2012:174).

Agama tersebut mengandung nilai-nilai kepercayaan yang masih diamalkan dalam kehidupan orang Jawa hingga saat ini, sehingga berpengaruh terhadap pola tata laku, norma, nilai dan aspek kehidupan lain. Orang Jawa juga percaya kepada suatu kekuatan yang melebihi segala kekuatan di mana saja yang pernah dikenal, yaitu kasakten, kemudian arwah atau ruh leluhur, dan makhlukmakhluk halus seperti misalnya memedi, lelembut, tuyul, demit serta jin dan lainnya yang menempati alam sekitar tempat tinggal mereka (Koentjaraningrat, 1997:347). Jadi, tidak mengherankan jika orang Jawa menggunakan sistem kepercayaan untuk memperoleh keselamatan, ketenangan, ketentraman, dan kebahagiaan hidup.
Kepercayaan Jawa tersebut masih berlaku di Alas Ketonggo yang terletak di Desa Babadan Kecamatan Paron, 12 km arah selatan Kabupaten Ngawi. Alas Ketonggo adalah lahan perhutanan, yang sama dengan hutanhutan lainnya ditumbuhi berbagai jenis pepohonan. Namun, Alas Ketonggo lebih dikenal masyarakat dibanding hutan-hutan lain di Kabupaten Ngawi, banyak orang yang datang ke tempat ini. Hal ini terlihat, pada hari-hari tertentu seperti Jum'at dan Selasa ramai dikunjungi masyarakat dari luar daerah.

Alas Ketonggo bukan tempat pariwisata yang mempunyai fasilitas hiburan sebagai daya tarik wisatawan. Kepariwisataan pada hakikatnya bertumpu pada keunikan, kekhasan, dan kelokalan serta keaslian sehingga menempatkan keanekaragaman sebagai suatu hal yang prinsip dan hakiki, maka pengembangan kepariwisataan pada dasarnya untuk kelestarian dan memperkukuh jati diri bangsa serta lingkungan alam (Muljadi.A.J, 2009:26).

\section{Keunikan Alas Ketonggo} yang dikunjungi banyak orang, tidak lepas dari pengaruh unsur budaya maupun sejarah yang mendukung perkembangannya. Disamping itu, 
adanya unsur budaya seperti sistem religi Jawa juga memiliki pengaruh dominan dalam wisata Alas Ketonggo. Oleh karena itu, orang melakukan kegiatan wisata bukan hanya karena kesenangan atau hobi saja. Namun, agama serta kebudayaan dapat pula menjadi alasan seseorang tertarik untuk berkunjung. Pariwisata merupakan suatu alat membangkitkan moral yang sehat, serta dapat membuat keseimbangan sifat-sifat yang emosional, sehingga memperoleh ketenangan dan kejernihan dalam berfikir.

Menurut Marji (wawancara tanggal 23 Februari 2013) memang banyak orang yang datang untuk ngalap berkah atau sekedar bermeditasi dengan berbagai alasan. Para pengunjung yang datang berasal dari lapisan masyarakat yang bervariasi. Mulai dari masyarakat dengan pendidikan SD, SMP, SMA sampai Perguruan Tinggi. Mereka datang dengan tujuan yang berbedabeda, diantaranya ngalap berkah, meminta agar karirnya lancar, mencari senjata atau barang pusaka sampai ada juga yang meminta jodoh dan minta diloloskan dari tes CPNS, atau hanya sekedar berkunjung untuk kegiatan wisata.
Para pengunjung biasanya datang pada tanggal 1 Muharam, Jum'at Legi, Jum'at Pon dan Selasa Kliwon pada bulan Muharam (Sura) dalam perhitungan kalender Jawa. Di Jawa dan bahkan bagian lain dari Indonesia banyak orang memperingati 1 Sura. 1 Sura dipandang sebagai hari sakral oleh orang Jawa. Kebanyakan dari mereka mengharapkan untuk ngalap berkah dari hari besar suci ini. Mereka berpuasa selama 24 jam, tidak tidur semalam suntuk dan ada pula yang melakukan meditasi secara khusuk (Purwadi, 2005:23).

Dengan demikian, Alas Ketonggo menjadi salah satu tempat yang dikunjungi masyarakat pada tahun baru Islam (bulan Muharam), sesuai ajaran kebudayaan Jawa. Pada era modern seperti saat ini, wisata Alas Ketonggo masih digemari oleh masyarakat, karena mereka mempunyai keyakinan kuat tentang kekuatan di luar kemampuan manusia biasa atau kekuatan makhluk gaib. Hal ini berarti bahwa ajaran kebudayaan Jawa masih banyak tercemin dalam kemajuan kehidupan masyarakat saat ini. Masyarakat menganggap Alas Ketonggo sebagai cagar budaya lokal yang harus dilestarikan, dengan 
segala nilai-nilai luhur budaya Jawa yang terkandung di dalamnya. Berdasarkan pandangan hidup orang Jawa, mengamalkan nilai ajaran agama atau kepercayaan sebaik mungkin, untuk memperoleh keselamatan dunia dan akhirat.

Alas Ketonggo juga sebagai tempat media interaksi sosial antar masyarakat dan juga para pengunjung. Keseluruhan masyarakat ikut berpartisipasi pada saat malam 1 Muharam, yang rutin dilaksanakan pertunjukan wayang kulit di Alas Ketonggo. Hal tersebut diwujudkan saat acara pertunjukan, seluruh warga desa dan pengunjung berkumpul menjadi satu. Komunikasi serta pembicaraan terjalin satu sama lain tanpa membedakan status sosial.

Pengunjung di Alas Ketonggo tidak melakukan hal-hal yang sifatnya syirik, seperti menyembah punden, pohon atau yang lainnya. Akan tetapi menurut pengamatan, para pengunjung hanya melakukan ritual mengambil tempat Alas Ketonggo sebagai tempat perantara untuk menyambung segala permintaan kepada Tuhan. Alas Ketonggo dianggap tempat yang cocok bermeditasi, memfokuskan fikiran untuk ngalap berkah, memperoleh keselamatan, ketenangan dan ketentraman hidup, karena Alas Ketonggo merupakan hutan yang teduh, dikelilingi ribuan pepohonan besar yang rindang dan letaknya jauh dari kebisingan laju kendaraan jalan raya, sehingga pengunjung memperoleh kenyamanan dan ketenangan.

Dari kebiasan inilah sehingga peneliti tertarik untuk mengkaji tentang wisata Alas Ketonggo yang menjadi daya tarik pengunjung dari berbagai daerah hingga saat ini, serta bagaimana dampak bagi kehidupan sosial dan religi masyarakat Desa Babadan Kecamatan Paron Kabupaten Ngawi.

Berdasarkan latar belakang
masalah dan batasan masalah
tersebut, maka dapat dirumuskan
permasalahan penelitiannya, sebagai
berikut:

1. Mengapa Alas Ketonggo dijadikan objek wisata?

2. Bagaimanakah kepercayaan masyarakat Desa Babadan Kecamatan Paron Kabupaten Ngawi terhadap Alas Ketonggo?

3. Bagaimana dampak Alas Ketonggo terhadap kehidupan sosio religi masyarakat sekitar 
Desa Babadan Kecamatan Paron

Kabupaten Ngawi?

\section{Tujuan Penelitian}

Dalam mengadakan

penelitian tidak terlepas dari tujuan yang hendak dicapai, sebab tujuan penelitian tersebut akan memberi arah dalam penelitian. Adapun yang menjadi tujuan dari penelitian ini, yakni:

1. Untuk mengetahui sejarah Alas Ketonggo yang dijadikan objek wisata.

2. Untuk mengetahui kepercayaan masyarakat Desa Babadan Kecamatan Paron Kabupaten Ngawi terhadap wisata Alas Ketonggo.

3. Untuk mengetahui dampak Alas Ketonggo terhadap kehidupan sosio religi masyarakat Desa Babadan Kecamatan Paron Kabupaten Ngawi.

\section{Kajian Pustaka}

\section{A. Wisata}

\section{Pengertian Wisata}

Wisata adalah berpergian kemana-mana untuk bersenang-senang (melihat-lihat atau menikmati keindahan alam, dsb) atau untuk mempelajari sesuatu menambah pengetahuan (Tim Penyusun Kamus, 1991: 1130).

Menurut Gamal Suwantoro (2004: 3), wisata merupakan suatu perjalanan yang dilakukan oleh seseorang atau lebih dengan tujuan antara lain untuk mendapatkan kenikmatan dan memenuhi hasrat ingin mengetahui sesuatu.

$$
\text { Pendapat lain }
$$

diungkapkan oleh Nyoman S. Pendit (2006: 3), bahwa istilah wisata berasal dari bahasa Sansekerta yaitu wis (man) berarti rumah, properti, kampung, komunitas, dan ata berarti pergi terus-menerus, mengembara, yang dirangkai menjadi satu kata wisata berarti pergi meninggalkan rumah (kampung) berkeliling terus-menerus.

Manusia merupakan makhluk sosial yang selalu membutuhkan orang lain untuk memenuhi berbagai 
kebutuhan hidupnya.

Sandang, pangan dan papan

adalah kebutuhan utama

manusia, selain kebutuhan itu

manusia juga membutuhkan

kebutuhan akan kesenangan

atau hiburan yang diperoleh

dengan melakukan kegiatan

wisata. Kegiatan wisata (tour)

yaitu suatu aktivitas

perubahan tempat tinggal

sementara dari seseorang, di

luar tempat tinggal sehari-

hari dengan suatu alasan apa

pun selain melakukan

kegiatan yang bisa

menghasilkan upah atau gaji

(Muljadi, 2010: 7).

Pendapat yang sama

juga diungkapkan oleh

Kodhyat (1996: 3), bahwa

kegiatan wisata adalah

perjalanan dan persinggahan

yang dilakukan oleh manusia

di luar tempat tinggalnya

untuk berbagai maksud dan

tujuan, tetapi bukan untuk

tinggal menetap di tempat

yang dikunjungi atau

disinggahi, atau untuk

melakukan pekerjaan-

pekerjaan dengan

mendapatkan upah.
Pada prinsipnya

kegiatan wisata dapat

mencakup semua macam

perjalanan, asal saja

perjalanan tersebut diikuti

dengan pertamasyaan dan

rekreasi. Perjalanan tersebut

diatas tidak bermaksud untuk

memangku suatu jabatan di

suatu tempat atau daerah

tertentu, sebab perjalanan

terakhir ini dapat

digolongkan ke dalam

perjalanan bukan untuk

tujuan pertamasyaan atau

pariwisata (Oka A. Yoeti,

2006: 177-178).

Dari berbagai

pendapat di atas dapat

disimpulkan bahwa wisata

adalah suatu perjalanan, yang

berangkat dari satu tempat

menuju dan singgah

kebeberapa tempat, dan

kembali lagi ketempat

semula, untuk mencari

kesenangan atau ketenangan

hidup. Kegiatan wisata

merupakan suatu media

interaksi antara manusia

dengan manusia, antara

kelompok manusia dengan

latar belakang sosial budaya 
yang berbeda, maupun antara

manusia

dengan

lingkungannya. Kegiatan

wisata dapat menimbulkan

berbagai dampak positif dan

negatif di berbagai bidang

kehidupan, yaitu ekonomi,

pendidikan, sosial budaya,

sikap dan jati diri.

\section{Objek Wisata}

Objek wisata adalah hal, perkara, orang yang menjadi pokok pembicaraan atau benda, hal, dan sebagainya yang dijadikan sasaran untuk diteliti, diperhatikan dan sebagainya dalam wisata (Tim Penyusun Kamus, 1991: 622).

$$
\text { Menurut Gamal }
$$

Suwantoro (2004: 19) objek wisata merupakan potensi yang bisa mendorong kehadiran wisatawan ke suatu daerah tujuan wisata. Objek wisata di kelompokkan menjadi tiga macam, yaitu:

a) Objek wisata alam

Objek wisata alam mempunyai daya tarik pada keindahan dan kekayaan alam. Objek wisata alam meliputi keindahan alam

pegunungan, sungai,

pantai, hutan dan sebagainya.

b) Objek wisata budaya

Objek wisata budaya mempunyai daya tarik tinggi karena memiliki nilai khusus dalam bentuk atraksi kesenian, upacara-upacara adat, nilai luhur yang terkandung dalam suatu objek buah karya manusia pada masa lampau.

c) Objek wisata minat khusus

Objek wisata minat khusus mempunyai daya tarik dengan adanya ciri khusus/spesifikasi yang bersifat langka. Misalnya, atraksi wisata merupakan ciptaan manusia seperti festival, pameran dan sebagainya.

Dengan demikian obyek wisata adalah semua hal yang menjadi daya tarik untuk dilihat, dirasakan dan dinikmati oleh wisatawan, yang dibuat manusia atau 
kekayaan alam. Contoh objek

wisata yang dibuat manusia

adalah wisata hasil

kebudayaan, wisata atraksi,

monumen, pameran dan

sebaginya. Contoh objek

wisata kekayaan alam yaitu

berupa pemandangan

pegunungan, pantai, sungai

dan sebagainya.

\section{B. Sosio Religi}

\section{Pengertian Sosio Religi}

Kata sosio berasal dari kata Yunani socius yang bearti kawan, teman (Supardi, 2011: 79). Pendapat yang sama juga diungkapkan oleh Dadang Supardan (2008: 69) bahwa sosio berasal dari kata Yunani socius bearti kawan, berkawan atau bermasyarakat.

$$
\text { Kata "religi" }
$$

merupakan terjemahan langsung dari bahasa asing religion, biasa diterjemahkan dalam bahasa Indonesia dengan perkataan "agama", yang berkaitan dengan sistem kepercayaan masyarakat yang masih hidup sampai saat ini (Kusnaka Adimihardja, 1983: 48).
Menurut Durkheim

dalam Anthony Giddens

(2005: 49), meyakini bahwa religi adalah hal paling primitif dari segala fenomena sosial. Semua manifestasi lain dalam aktivitas kolektif berasal dari agama dan melalui berbagai transformasi secara berturutturut: antara lain menyangkut hukum, moral, seni, bentuk politik dan sebagainya.

Budiono Herusatoto (2008: 42) berpendapat bahwa, pada pokoknya religi adalah penyerahan diri manusia kepada Tuhan, dalam keyakinan bahwa manusia itu tergantung dari Tuhan, bahwa tuhanlah yang merupakan keselamatan yang sejati dari manusia, bahwa manusia dengan kekuatannya sendiri tidak mampu untuk memperoleh keselamatan itu dan karenanya ia menyerahkan dirinya.

$$
\text { Dari berbagai }
$$
pernyataan di atas dapat disimpulkan bahwa sosio religi merupakan sistem kepercayaan dan keyakinan 
di dalam masyarakat.

Kepercayaan itu diyakini kebenarannya oleh

masyarakat, sehingga

menjadi kepercayaan

keagamaan atau kepercayaan

religius. Kepercayaan

keagamaan ini diwujudkan

dalam berbagai bentuk

kegiatan masyarakat, yaitu

mengadakan

upacara

perkawinan, kelahiran juga

kematian, dan mempercayai

suatu tempat, benda, waktu

atau orang sebagai yang

keramat, suci, bertuah, atau

istimewa.

Mempercayai sesuatu

sebagai yang suci atau sakral

itu merupakan ciri khas

kehidupan beragama.

Kehidupan beragama pada

dasarnya merupakan

kepercayaan terhadap

keyakinan adanya kekuatan

gaib, luar biasa atau

supernatural yang

berpengaruh terhadap

kehidupan individu dan

masyarakat, bahkan terhadap

segala gejala alam

(Bustanuddin Agus, 2009: 3).
Menurut Durkheim

dalam Imam Muhni (1994:

128) bahwa religi merupakan sesuatu yang tidak dapat dielakkan dalam kehidupan masyarakat. Pembagian dunia dalam yang sakral dan yang profane merupakan ciri khas pemikiran religius. Hal-hal yang sakral bukan diartikan dewa-dewa atau roh-roh, melainkan apa saja yang dapat menjadi sakral atau dijadikan sakral.

Menurut Imam Budhi Santosa (2012: 241), bahwa penduduk asli di Jawa telah mempunyai sistem religi (kepercayaan) yang dianut dan diamalkan dalam kehidupan kesehariannya. Inti dari religiositas ini adalah, mereka percaya mengenai adanya roh atau jiwa pada manusia, hewan, tumbuhan, dan benda-benda lain di dunia. Disamping itu, mereka juga percaya akan adanya roh adikodrati, yang paling tinggi (paling berkuasa) mengatur kehidupan manusia. Sistem religi masyarakat merupakan 
ekspresi spiritual seseorang yang berkaitan dengan sistem keyakinan, nilai dan hukum yang berlaku. Manusia mempercayai berbagai kekuatan di luar dirinya yang memiliki daya yang luar biasa dalam mengendalikan kehidupan mereka, sehingga berpengaruh terhadap pola tata laku, norma, nilai dan aspek kehidupan lain.

\section{Unsur-Unsur Religi}

Suatu sistem religi
selalu mempunyai unsur-
unsur yang penting untuk
memelihara agama serta para
penganutnya.
Koenjtaraningrat (2009: 295-
297), berpendapat bahwa
unsur penting dalam religi,
yaitu:

a. Emosi Keagamaan

Semua aktivitas manusia yang bersangkutan dengan religi berdasarkan atas suatu getaran jiwa, yang biasanya disebut emosi keagamaan (religious emotion). emosi keagamaan ini biasanya pernah dialami oleh setiap manusia, walaupun

getaran emosi itu mungkin hanya berlangsung untuk beberapa detik saja, untuk kemudian menghilang lagi. Emosi keagamaan itulah yang mendorong orang melakukan tindakantindakan bersifat religi. Emosi keagamaan menyebabkan bahwa suatu benda, suatu benda, suatu tindakan, atau gagasan, mendapat suatu nilai keramat (sacred value) dan dianggap keramat. Demikian juga benda-benda, tindakantindakan, atau gagasangagasan yang biasanya yang tidak keramat (profane), tetapi apabila dihadapi oleh manusia yang dihinggapi oleh emosi keagamaan sehingga ia seolah-olah terpesona, maka bendabenda, tindakan-tindakan, dan gagasan tadi menjadi keramat. 
b. Sistem Keyakinan

Mengenai ini para ahli antropologi biasanya menaruh perhatian terhadap konsepsi tentang dewa-dewa yang baik maupun yang jahat, sifat dan tanda dewadewa, konsepsi tentang makluk-makluk halus lainnya seperti roh-roh leluhur, ro-roh lain yang baik maupun yang jahat, hantu, serta konsep tentang dewa tertinggi dan pencipta alam.

c. Sistem Upacara Keagamaan

Sistem upacara keagamaan secara khusus mengandung empat aspek yang menjadi perhatian khusus dari para ahli antropologi ialah:

1) Tempat-tempat keramat upacara dilakukan, yaitu makam, candi, pura, kuil, gereja, langgar, surau, masjid dan sebagainya.

2) Saat-saat upacara keagamaan dilakukan, yaitu saat-saat

beribadah, hari-hari keramat dan suci.

3) Benda-benda yang dipakai saat upacara, termasuk patungpatung, yang melambangkan dewadewa, alat bunyibunyian seperti lonceng suci, seruling suci, genderang suci, dan sebagainya.

4) Orang-orang yang melakukan dan memimpin upacara, yaitu para pendeta biksu, syaman, dukun, dan lain-lain.

d. Suatu Umat yang Menganut Religi

Secara khusus subunsur ini mengikuti masalah pengikut suatu agama, hubungannya satu dengan yang lain, hubungannya dengan para pemimpin agama, baik dalam saat adanya upacara keagamaan maupun dalam kehidupan sehari-hari, dan akhirnya 
subunsur ini juga meliputi

masalah

seperti

organisasi dari para umat,

kewajiban, serta hak-hak

para warganya.

Dengan demikian wisata bukan hanya untuk memperoleh kesenangan atau hiburan saja. Namun, wisata juga untuk memperoleh ketenangan hati berkaitan dengan nilai religius yaitu wisata religi. Kegiatan wisata merupakan suatu media interaksi antara kelompok manusia dengan latar belakang sosial budaya yang berbeda. Sebagai suatu media interaksi wisata dapat menimbulkan dampak masyarakat maupun perorangan. Hubungan wisata dengan sosio religi diharapkan memiliki dampak positif pada nilainilai religius yang tidak menyimpang dengan norma dan budaya masyarakat.

Metode Penelitian

\section{A. Tempat dan Waktu Penelitian}

\section{Tempat Penelitian}

Lokasi atau tempat penelitian ini dilaksanakan di
Desa Babadan Kecamatan Paron Kabupaten Ngawi. Desa Babadan merupakan desa yang letaknya jauh dari Kota Ngawi. Desa ini memiliki keadaan sosial ekonomi yang belum maju, sebagian besar masyarakatnya bermata pencaharian sebagai petani.

Namun, di lingkungan masyarakat tersebut terdapat potensi yang menjadi daya tarik tersendiri yakni obyek wisata Alas Ketonggo. Adanya obyek wisata tersebut memberikan dampak berupa perubahan dari berbagai aspek kehidupan masyarakat. Salah satunya, yakni perubahan sistem kepercayaan masyarakat. Hal inilah yang menjadi keunikan tersendiri sebagai ciri khas pada suatu daerah.

\section{Waktu Penelitian}

Penelitian dilakukan selama satu semester, pada bulan Februari hingga Juni 2013.

B. Pendekatan dan Jenis Penelitian

Pendekatan ini menggunakan metode kualitatif. 


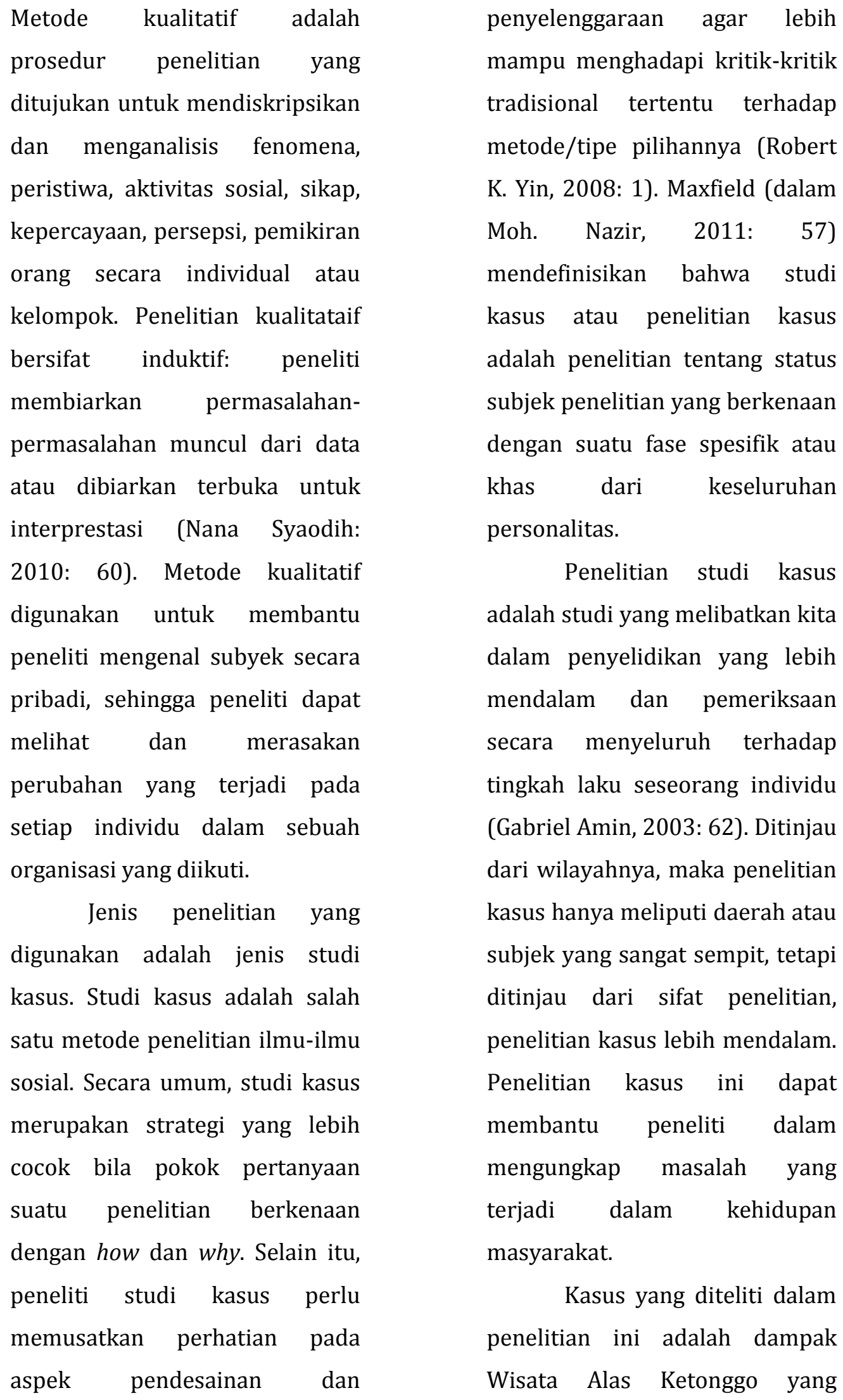


berada di Desa Babadan

Kecamatan Paron Kabupaten

Ngawi dalam aspek sosiologi dan

religi. Alas Ketonggo merupakan

wisata spiritual Jawa yang masih

menjadi daya tarik pengunjung

sampai saat ini. Hal ini

membuktikan bahwa ajaran

kebudayaan Jawa masih banyak

tercemin dalam kemajuan

kehidupan masyarakat saat ini.

Masyarakat menganggap Alas

Ketonggo sebagai cagar budaya

lokal yang harus dilestarikan.

\section{Sumber Data, Sampel dan}

\section{Teknik Pengumpulan Sampel}

\section{Sumber Data}

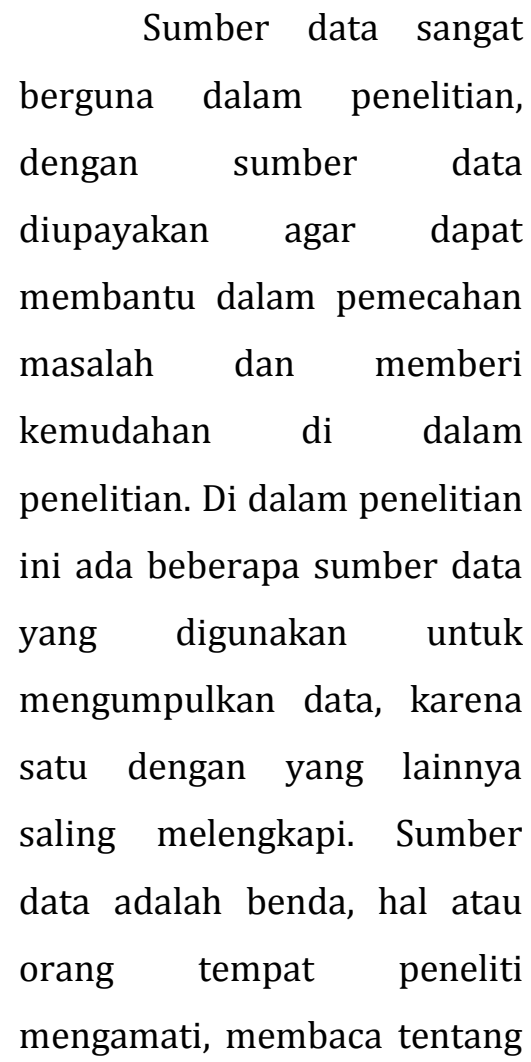

data (Suharsimi Arikunto, 2010: 172). Jenis sumber data yang digunakan dalam penelitian ini adalah:

\section{a. Sumber Data Primer}

Sumber data primer adalah data dalam bentuk verbal atau kata-kata yang diucapkan secara lisan, gerak gerik atau perilaku yang dilakukan oleh subjek yang dapat dipercaya (Suharsimi Arikunto, 2010: 22). Sumber data primer yang digunakan dalam penelitian ini adalah berupa data yang didapat dari wawancara sumber pertama yaitu juru kunci Alas Ketonggo, kepala Desa Babadan, perangkat Desa Babadan, serta masyarakat sekitar Alas Ketonggo. Bentuk dari sumber datanya berupa hasil dari wawancara yang telah dilakukan oleh peneliti.

b. Sumber Data Sekunder

Sumber data
sekunder adalah data
tangan kedua atau data
sekunder yang biasanya
diperoleh dari otoritas atau


pihak yang berwenang mempunyai efisiensi yang tinggi tetapi kadang kurang akurat (Saifuddin Azwar, 2004: 92). Sumber data Sekunder yang dipakai dalam penelitian ini berupa sumber-sumber pustaka yang diambil dari bukubuku induk antropologi dan wisata. Selain sumbersumber pustaka, ada pula dokumen-dokumen yang diambil dari kantor desa.

\section{Sampel dan Teknik} Pengumpulan Sampel

Sampel (contoh) adalah sebagian individu yang diselidiki dari keseluruhan individu penelitian. Sutrisno Hadi dalam Abu Achmadi (1999: 107). Pada penelitian ini peneliti mengambil 21 sampel dari seluruh jumlah penduduk Desa Babadan untuk dijadikan sebagai bahan penelitian. 21 orang yang dijadikan sampel ini dianggap sebagai pihak yang informasinya cukup relevan untuk dijadikan sebagai sumber. Orang-orang tersebut merupakan pihak-pihak yang memiliki keterangan cukup lengkap bila dibandingkan dengan yang lain.

Teknik pengambilan sampel yang digunakan adalah teknik purposive sampling atau sampel bertujuan. Teknik ini dipilih karena purposive sampling didasarkan atas ciriciri tertentu yang dipandang mempunyai sangkut paut yang erat dengan populasi yang diketahui sebelumnya. Unit sampel yang dihubungi disesuaikan dengan kriteriakriteria tertentu yang diterapkan berdasarkan tujuan penelitian (Nurul Zuriah, 2006: 124).

Peneliti secara khusus memilih sampel berdasarkan tujuan penelitiannya, yaitu peneliti menentukan 15 sampel sebagai sasaran untuk dijadikan sumber sebagai bahan penelitian. Sampel yang ditentukan oleh peneliti berdasarkan pada beberapa pertimbangan yaitu orang yang dipilih sebagai sampel sesuai dengan tema yang ditentukan, sehingga peneliti 
akan mendapatkan informasi sesuai kebutuhan.

\section{Teknik Pengumpulan Data}

$$
\text { Sesuai dengan }
$$

pendekatan penelitian kualitatif dan sumber data yang digunakan, maka teknik pengumpulan data dalam penelitian ini menggunakan beberapa teknik, yaitu:

\section{Wawancara}

Wawancara adalah suatu kegiatan yang dilakukan untuk mendapatkan informasi secara langsung dengan menggunakan pertanyaan pada para responden (Joko Subagyo, 2004: 39). Metode wawancara digunakan untuk memperoleh data yang sifatnya primer atau pokok dari informan oleh peneliti. Metode ini merupakan metode untuk mendapatkan informasi dengan mengajukan pertanyaan langsung dan terbuka kepada informan. Jenis wawancara yang dipilih oleh peneliti yaitu jenis wawancara terpimpin atau wawancara yang menggunakan konsep wawancara. Jenis ini dipilih sebab untuk memudahkan pewawancara merinci datadata yang nantinya diperoleh. Selain itu pewawancara dapat mengembangkan suatu kerangka pertanyaan untuk mencari jawabannya yang mengarah pada suatu pembuktian dari prediksinya

\section{Observasi}

Observasi biasa diartikan sebagai pengamatan dan pencatatan secara sistematik terhadap gejala yang tampak pada obyek penelitian. Observasi langsung dilakukan terhadap objek ditempat terjadi atu berlangsungnya peristiwa, sehingga obsever berada bersama obyek yang diselidikinya (Joko Subagyo, 2004: 100). Observasi merupakan salah satu teknik pengumpulan data yang memerlukan ingatan kuat terhadap observasi yang dilakukan sebelumnya.

Terdapat dua jenis observasi, yakni observasi partisipan dan obsevasi non partisipan. Jenis observasi yang dipilih peneliti yakni 
observasi non partisipan.

Peneliti tidak ikut di dalam kehidupan obyek yang akan diobservasi, dan secara terpisah berkedudukan selaku pengamat. Di dalam hal ini peneliti hanya bertindak sebagai penonton saja tanpa harus ikut terjun langsung ke dalam acara. Pada observasi ini peneliti mendatangi peristiwanya. Kehadiran dan peran peneliti di lokasi bersifat pasif, sebab kehadirannya sebagi orang asing diketahui oleh yang diamati, dan bagaimanapun hal itu membawa pengaruh pada yang diamati.

Tujuan observasi atau pengamatan ini adalah untuk melihat serta mengamati kegiatan Wisata Alas Ketonggo. Hal-hal yang perlu diamati atau diobservasi diantaranya yaitu waktu pelaksanaan dan makna simbolis yang terkandung dalam tempat wisata serta pihak-pihak yang terlibat di dalamnya. Selain itu kegiatan observasi bertujuan untuk mengetahui bagaimana pengaruh Wisata Alas Ketonggo terhadap kehidupan sosial dan keagamaan Desa Babadan.

\section{Dokumentasi}

Metode dokumentasi yaitu mencari data mengenai hal-hal atau variabel yang berupa catatan, transkrip, buku, surat kabar, majalah, prasasti, notulen rapat, legger, agenda dan sebagainya (Suharsimi Arikunto, 2010: 201). Metode ini salah satu cara yang memudahkan dalam kegiatan penelitian, karena dalam melakukan penelitian harus ada sumber yang relevan dan mendukung sehingga penelitian yang dilakukan dapat berjalan lancar.

Jenis dokumentasi yang dipilih dalam penelitian ini yaitu dokumentasi primer dan dokumentasi sekunder. Dokumentasi primer diperoleh melalui hasil observasi dan hasil wawancara. Hasil observasi yang diperoleh berupa hasil pengamatan langsung oleh peneliti yang kemudian 
dideskripsikan dalam
penelitian ini. Sedangkan hasil
wawancaranya berupa
keterangan-keterangan dalam
bentuk rekaman yang diubah
dalam bentuk tulisan oleh
peneliti.

Selain sumber primer, ada pula sumber sekunder yang dipakai dalam penelitian ini. Sumber-sumber sekunder yang didapat berasal dari sumber yang diambil selain manusia, diantaranya profil Desa Babadan, serta foto-foto tempat wisata, dan dokumen. Bentuk dokumen di atas dianggap memberikan berbagai keuntungan yang diantaranya ialah bahwa bahan itu telah ada, telah tersedia dan siap pakai. Selain itu, penggunaannya tidak meminta biaya, hanya memerlukan waktu untuk mempelajarinya. Banyak pengetahuan yang diperoleh dari bahan itu bila dianalisis dengan cermat yang berguna bagi penelitian.

\section{E. Prosedur Penelitian}

Penelitian tentang wisata alas ketonggo Desa Bababadan ini dilakukan kurang lebih selama 5 bulan yaitu dimulai pada bulan Februari 2013 sampai Juli 2013 yang tersusun dalam tahapantahapan penelitian sebagai berikut:

\section{Tahap Persiapan}

Tahap persiapan penelitian ini menyangkut penentuan tema dan pengajuan judul, pengamatan atau observasi awal. Kegiatan-kegiatan tersebut dilakukan pada bulan Februari. Setelah mendapat persetujuan mengenai tema dan judul penelitian dari dosen pembimbing, maka kegiatan selanjutnya adalah mengadakan pengamatan awal terhadap objek penelitian agar memperoleh gambaran tentang lokasi penelitian dan narasumber yang akan dijadikan informan untuk mendukung pelaksanaan penelitian.

\section{Tahap Pelaksanaan}

$$
\text { Kegiatan }
$$

dilakukan dalam tahap ini adalah pengumpulan data dari lapangan. Langkah awal untuk memperoleh data 
lapangan adalah mencari

informasi di kantor desa agar dapat memperoleh gambaran masyarakat, kemudian dilanjutkan dengan mencari informasi pada sejumlah informan yang relevan dengan aspek penelitian. Proses pencarian informasi menggunakan teknik purposive sampling sehingga tidak sulit dalam mengumpulkan data, karena data diperoleh sesuai tujuan penelitian melalui wawancara dengan pihakpihak yang sudah ditentukan sebelumnya.

\begin{tabular}{l}
\multicolumn{2}{c}{ Setelah data-data } \\
terkumpul maka dilakukan \\
penganalisisan data serta \\
kegiatan yang telah dilakukan \\
untuk mempermudah \\
penyusunan
\end{tabular}

Langkah awal analisis yaitu dimulai dengan reduksi data untuk menyeleksi keabsahan data, kemudian proses selanjutnya yaitu menyajikan data dan penarikan kesimpulan atau proses verifikasi data. Bilamana setelah melalui ketiga tahapan tersebut data yang diperoleh kurang memadai maka akan dilakukan pencarian kekurangan data sehingga penelitian akan benar-benar teruji kevalidannya.

\section{Tahap Penyelesaian}

Tahap penyelesaian ini berupa penyusunan laporan hasil penelitian. Setelah temuan dapat dirumuskan dengan jelas, laporan disusun secara obyektif dan sistematis sesuai data yang ada, sehingga validitas hasil penelitian dapat tercapai dan penyusunan hasil penelitian dapat tersaji dengan baik.

Secara terperinci penelitian ini dapat diketahui melalui jadwal penelitian yang dimulai sejak pengajuan judul sampai kegiatan akhir yaitu penyusunan hasil penelitian yang telah melalui analisis dan berbagai revisi.

\section{F. Teknik Keabsahan Data}

Untuk menguji menguji kredibilitas data dalam penelitian kualitatif, dapat dilakukan dengan trianggulasi yaitu teknik pengumpulan data yang bersifat 
menggabungkan dari berbagai

teknik pengumpulan data dan

sumber data yang telah ada. Bila

peneliti melakukan pengumpulan

data dengan trianggulasi, maka

sebenarnya

peneliti

mengumpulkan data sekaligus

menguji kredibilitas data, yaitu

mengecek kredibilitas data

dengan berbagai teknik

pengumpulan data dan berbagai

sumber data (Sugiyono, 2010:

330). Trianggulasi ini akan

mendorong peneliti dalam

mengembangkan suatu laporan

yang akurat dan kredibel.

Adapun jenis triangulasi

data yang digunakan pada

penelitian ini adalah teknik

triangulasi sumber. Triangulasi

sumber merupakan cara

mengarahkan peneliti agar di

dalam mengumpulkan data wajib

menggunakan beragam sumber

data yang tersedia dan berbeda-

beda, dengan demikian data yang

diperoleh dari sumber satu akan

lebih teruji kebenarannya apabila

dibandingkan dengan data

sejenis yang berbeda sumbernya

(H.B.Sutopo, 2006: 93).

Triangulasi sumber berarti, untuk mendapatkan data dari berbagai sumber yang berbeda-beda

dengan teknik yang sama

(Sugiyono, 2010: 330).

Teknik triangulasi

sumber dapat dilakukan dengan

cara menggali sumber-sumber

data yang berbeda jenisnya,

seperti menggunakan sumber

dari informan, dalam hal ini

diambil dari hasil wawancara

dengan perangkat desa, tokoh

masyarakat, dan masyarakat

sekitar. Selain itu sumber data

juga dapat diambil dari arsip atau

dokumen, serta pengamatan atau

observasi terhadap objek kajian

yang akan diteliti.

Alasan pemilihan

triangulasi sumber yaitu

penelitian ini difokuskan

terhadap kajian sosio religi

wisata alas ketonggo, oleh sebab

itu memerlukan beberapa

sumber untuk menggali

informasi, seperti memerlukan

beberapa informan untuk

membandingkan pandangan yang

ada dalam masyarakat.

Penggunaan triangulasi ini

diharapkan dapat

membandingkan data yang

diperoleh dari beberapa sumber,

dengan upaya penggalian data 
yang diambil dari sumber dan penggunaan teknik pengumpulan data yang berbeda-beda dapat teruji kebenarannya sehingga mengahasilkan data yang valid.

Adapun secara singkat teknik triangulasi sumber dapat dilihat dari bagan di bawah ini:

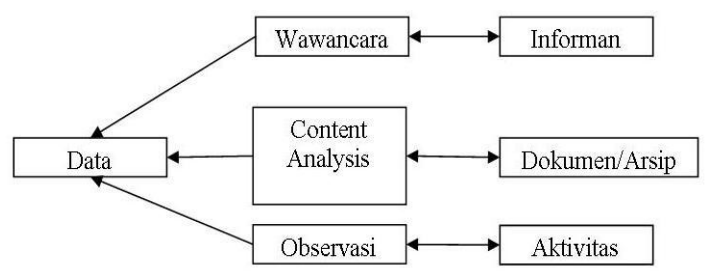

Bagan 3.1 Triangulasi Sumber (H.B.Sutopo, 2006: 94)

\section{G. Teknik Analisis Data}

Analisis data adalah
proses mencari dan menyusun
secara sistematis data yang
diperoleh dari hasil wawancara,
catatan lapangan, dan
dokumentasi, dengan cara
mengorganisasikan data kedalam
kategori, menjabarkan ke dalam
unit-unit, melakukan sintesa,
menyusun ke dalam pola,
memilih mana yang penting dan
yang akan dipelajari, dan
membuat kesimpulan sehingga
mudah difahami oleh diri sendiri
maupun orang lain (Sugiyono,
2010:335).

Dalam proses analisis data terdapat tiga komponen yang harus dipahami dan diperhatikan oleh setiap peneliti, khususnya pada penelitian kualitatif. Tiga komponen tersebut adalah:

\section{Data Reduction (Reduksi} Data)

Reduksi data diartikan sebagai proses pemilihan, pemusatan perhatian pada penyederhanaan,

pengabstrakan dan transformasi data "kasar" yang muncul dari catatancatatan tertulis di lapangan. Sebagaimana kita ketahui, reduksi data, berlangsung terus-menerus selama proyek yang berorientasi kualitatif berlangsung (Mattew B. Miles dan A. Michael Huberman, 1992: 16). Dengan demikian, data yang direduksi dapat memberi gambaran yang lebih jelas, hingga kesimpulankesimpulan finalnya dapat ditarik dan diverifikasi.

\section{Data Display (Penyajian Data)}

Kami membatasi suatu "penyajian" sebagai 


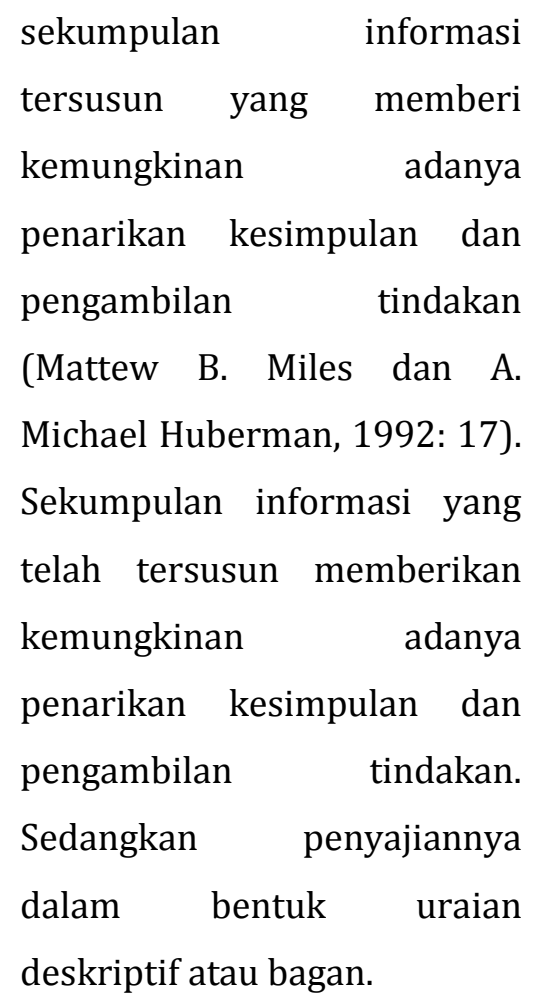

\section{Penarikan Kesimpulan} (Verification)

Dari permulaan pengumpulan data, seseorang menganalisis kualitatif mulai mencari arti benda-benda mencatat keteraturan, polapola penjelasan, konfigurasikonfigurasi yang mungkin alur sebab-akibat dan proporsisi (Mattew B. Miles dan A. Michael Huberman, 1992: 19). Di dalam proses ini peneliti berupaya untuk memberi intepretasi terhadap hasil analisis data. Tahap ini merupakan suatu tahap pemikiran kembali yang

melintas dalam pikiran penganalisa selama ia menulis atau suatu tinjauan ulang pada catatan-catatan lapangan.

Analisis merupakan
proses dalam penelitian atau
pencarian dan perencanaan
secara sistematik semua data dan
bahan lain yang terkumpul, agar
peneliti mengerti benar makna
yang telah dikemukakan dan
dapat menyajikan kepada yang
lain secara jelas. Data mentah
yang terkumpul di lokasi
penelitian hasil dari wawancara
maupun observasi ditulis dengan
rapi, terperinci, dan sistematis.
Langkah selanjutnya
adalah melakukan reduksi data,
yaitu pemilihan hal-hal pokok
yang sesuai dengan fokus
penelitian, pemusatan perhatian
pada penyederhanaan catatan-
catatan tertulis di lapangan.
Temuan di lapangan yang telah
direduksi kemudian dilakukan
penyusunan data dengan
membuat sajian data berupa
rangkaian kalimat yang disusun
secara logis dan sistematis,
sehingga mudah dibaca dan
disajikan. Dari penyajian data


tersebut akan ditemukan pokok-

pokok temuan yang penting.

Temuan-temuan

tersebut

dijadikan acuan dalam menarik

kesimpulan. Simpulan perlu

diverifikasi agar hasil penelitian

benar-benar dapat dipertanggung jawabkan.

\section{Hasil Penelitian}

\section{A. Sejarah Wisata Alas Ketonggo}

Wisata Alas Ketonggo merupakan wisata religi yang terletak di area hutan jati milik Perhutani RKPH Kuncen dan Babadan yang berada di wilayah Desa Babadan tepatnya di Dusun Brendil. Sejarah Desa Babadan tidak terlepas dari sejarah dari masyarakat primitif di Kabupaten Ngawi. Desa ini awalnya pecahan dari Desa Gentong dan Semen, waktu itu Kepala Desa adalah Bapak Proyo Sentono yang menjabat selama 30 tahun. Desa Babadan yang terdiri dari 4 kasun merupakan desa paling selatan di Kecamatan Paron. Nama Babadan diambil dari sebuath keagiatan pembukaan lahan (babat) hutan, sehinnga diberi nama Desa
Babadan (wawancara dengan Surawan 25 April 2013).

Pada awalnya Alas Ketonggo bernama Punden Syeh Dumbo yang ditemukan zaman Belanda tahun 1930. Waktu membuat jalur lori ada pohon yang akan ditebang tidak bisa roboh, hingga salah satu pembesar Belanda datang dengan mengendarai kuda dan meninggal di Alas Ketonggo. Kemudian ada roh yang masuk ke dalam tubuh salah satu warga dan roh itu berkata apabila akan mengadakan hajatan harus memberikan sedekah di Alas Ketonggo agar semuanya selamat (Wawancara dengan Marji 25 April 2013).

Menurut Bapak Marji sebagai juru kunci di Alas Ketonggo, bahwa Alas Ketonggo ini mempunyai hubungan silsilah legenda dengan Kerajaan Majapahit, yaitu Prabu Brawijaya V yang singgah di sini melepaskan baju kebesaran meneruskan perjalanan ke Puncak Lawu menerima gelar Sunan Lawu. Prabu Brawijaya pergi ke Alas Ketonggo setelah dari Alas Purwa di Banyuwangi karena berselisih 
pendapat dengan Prabu

Glendrawardana dari Kediri.

Sejak tahun 1974 Alas

Ketonggo di buka sebagai tempat wisata religi oleh bapak Summo Darmajdi (kades) dan beliau berpesan bahwa "kalau bertempat di Alas Ketonggo diminta untuk damai dan tentram". Setelah itu banyak pengunjung yang mulai datang ke Alas Ketonggo untuk menenangkan fikiran atau untuk tujuan lain, seperti mencari pekerjaan, naik drajat, mencari jodoh dan lain-lain. Namun, keseluruhan itu tergantung kesungguhan pengunjung berserah diri memohon kepada yang kuasa, di Alas Ketonggo hanya sebagai tempat perantara kepada Tuhan, bukan untuk hal syirik "ujar Marji". Kesehariannya

Alas Ketonggo ini dijaga dan dirawat oleh seorang juru kunci. Karena kompleks Alas Ketonggo berada di bawah kekuasaan warga lingkungan Babadan, maka juru kunci pun ditunjuk dari dan oleh masyarakat Babadan sendiri. Juru kunci Alas Ketonggo saat ini adalah Bapak Marji. Ia sudah cukup lama menjabat sebagai juru kunci, yang mana masa-masa sebelumnya selalu dipegang oleh orang tua dan pendahulunya. Status juru kunci ini hampir selalu dipegang oleh orang dalam keluarganya, dan inilah yang terjadi sejak dulu secara turun temurun. Pengelolaan Alas Ketonggo ini dilakukan oleh juru kunci dan tokoh masyarakat setempat. Hasil kotak amal setiap bulan dibukukan dan selanjutnya dipergunakan untuk biaya perawatan Alas Ketonggo, listrik dan kebutuhan lainnya.

Banyak situs banyak tempat, pengunjung harus menyesuaikan tempat dan tujuan datang ke Alas Ketonggo, karena banyak situs yang menjadi daya tarik pengunjung, diantaranya ada lebih dari sepuluh tempat atau situs wisata religi. Masing-masing tempat mempunyai nilai filosofi yang berbeda, jadi pengunjung harus memenyesuaikan tempat dan tujuannya sesuai nilai filosofi yang sudah diyakini di Alas Ketonggo. Tempat-tempat situs di Alas Ketonggo, diantaranya adalah:

1. Goa Tugu Manik

Tugu manik ini mengandung bahsa sastra yang artinya "kita masih muda didididk untuk sekolah harus yang tegak dan 
bisa membedakan mana yang

salah dan mana yang benar".

2. Goa Blegonondo

Goa ini bertingkat sampai 3

tingkatan, artinya kita

menerima apapun jangan

langsung atau dimakan

mentah-mentah, tapi harus

difikir selembut-lembutnya.

3. Goa Ndaru Kilat

Goa Ndaru Kilat mengandung makna "kita jangan berdiam tapi bisa menerima mana yang baik dan yang benar".

4. Goa Bagus

Goa ini bertanda dua buah pohon beringin yang sejajar, dari dulu hingga saat ini di sini tidak ada goa yang berwujud. Artinya "ini bertanda mengingatkan kita bahwa asal-usul kita dari ke dua orang tua yaitu ayah dan ibu". Kita dilahirkan dari Goa Garbo Ibu dan do'a kedua orang tua mendo'akan supaya anaknya sholeh dan sholekhah, serta beriman dan berbakti kepada kedua orang tua.

5. Goa Mandra Guna Artinya kita berfikir dengan indera ke enam (batin), paling dalam untuk menuju jalan paling benar.

6. Sendang Soko

Artinya kita berdiri menghadap kepada Ynag Maha Kuasa dengan jalan yang benar.

7. Sendang umbul Jambe

Artinya untuk sumber kehidupan di tengah pulau sungai yang mengandung makna dalam perjalanan hidup pasti ada rintangan.

8. Siti Inggil

Artinya kita mencari tempat untuk berdo'a mendekat kepada Tuhan Yang Maha Kuasa

9. Keraton Ketonggo

Mengandung makna seperti terjadi di depan kita sedang bergetar di "Honggo" orang Jawa menyebutnya. Sehingga disebut Keraton Ketonggo.

10. Batok Bolu/Batu Timbang Artinya kita berfikir berat, di timbang-timbang mana yang perlu di dahulukan dan mana yang masih bisa di tunda juga perlu dipertimbangkan untung dan rugi suatu keputusan yang akan diambil dalam perjalanan hidup kita. 
11. Goa Teluk

Dimulai dari silsilah Sinuwun

Brawijaya, goa ini mengahadap ke timur dan di tebing atas gua ada pohon beringin, yang tumbuh tapi tidak bisa berkembang. Ini bertanda bahwa orang yang besar dan kecil, jangan di pandang kebesarannya atau kekecilannya tetapi diambil artinya atas pengetahuan yang baik dan berguna untuk bangsa dan negara.

12. Kori Gapit

Artinya dalam perjalanan hidup kita membuka hati lebih hati-hati.

13. Palenggahan Agung Srigati

Artinya apabila kita mempunyai tanggung jawab sekalipun Kepala Rumah Tangga harus bisa menuju jalan kebenaran.

14. Tugu Mas

Artinya seseorang apabila sudah mempunyai tanggung jawab harus yang tegak, yang benar. Kelihatan jelek tempatnya tapi aslinya bagus namanya, karena nama baik mahal harganya. Beberapa situs di Alas Ketonggo ini yang sering di kunjungi adalah Sendang Umbul Jambe dan Palenggahan Agung Srigati, kedua tempat ini diyakini merupakan tempat petilasan Prabu Brawijaya yang mempunyai makna filosofi tersendiri bagi pengunjung. Keseluruhan makna dari situs Alas Ketonggo merupakan ajaran kehidupan yang disarankan, untuk mencapai berkah yang diharapkan. Namun, tidak semua dari pengunjung bisa menjalankan tergantung niat dan keasungguhan pribadi masingmasing.

Memasuki Alas Ketonggo, para pengunjung langsung dapat melihat Pesanggrahan Agung Srigati (petilasan Prabu Brawijaya), berupa sebuah rumah kecil berukuran $4 \times 3$ meter. Di dalamya terdapat gundukan tanah, yang dari ke hari semakin tinggi, sehingga gundukan tanah semakin banyak. Dinding rumah itu dikitari bendera panjang Merah Putih. Ada juga tombak dan barangbarang lain peninggalan majapahit, khas tempat sakral 
pasenggrahan Srigati ini pekat dengan bau dupa. Di sekitar gundukan tanah tersebut berserakan bungan tabor yang selalu disebarkan para pengunjung.

Fasilitas di sekitar petilasan meliputi antara lain: 2 unit bangunan tempat dzikir, sumur dan MCK, sebuah mushalla di komplek ini sehingga kalau diantara peziarah hendak melakukan shalat.. Pemandangan yang bisa dilihat bahwa di pohon banyak bekas-bekas sesaji bunga oleh pengunjung, di Petilasan Srigati juga ada bekas dupa oleh pengunjung. Di sungai juga ada yang mandi membersihkan diri, sudah menjadi kepercayaan sebagian pengunjung, salah satu ritualnya adalah setiap pengunjung yang mempunyai hajat tertentu harus mandi di Kali Tempuran untuk membersihkan diri dari hadas kecil dan besa (dalam Islam), kemudian baru memulai ritualnya (wawancara dengan Marji 25 April 2013).

\section{B. Kegiatan Pengunjung di Alas}

\section{Ketonggo}

Alas Ketonggo merupakan wisata religi yang sampai sekarang masih sering dikunjungi masyarakat. Hari-hari biasa selalu saja ada pengunjung yang datang, meskipun yang paling ramai adalah pada Bulan Sura. Alas Ketonggo dikunjungi masyarakat dari berbagai daerah di luar Kabupaten Ngawi, diantaranya dari Kediri, Lamongan, Solo, Sragen, Banyuwangi sampai Bali bahkan Malaysia. Mereka umumnya datang secara berombongan dengan mencarter kendaraan umum (wawancara dengan Marji 25 April 2013).

Jumlah pengunjung pada hari-hari biasa, selain pada Bulan Sura, tidaklah terlalu banyak. Jika dibuat rata-rata, kurang lebih sekitar 1-5 orang per hari. Tetapi jumlah itu meningkat pada saat hari Bulan Sura, khususunya pada hari Jum'at Pon dan Jum'at Legi, kurang lebih sekitar $10 \mathrm{~s} / \mathrm{d} 50$ orang. Hal ini dikarenakan Bulan Sura dianggap sebgai bulan suci masyarakat Jawa, 
sehingga tepat untuk ngalap

berkah atau meminta permohonan (wawancara dengan Sri 25 April 2013).

Pengunjung

Alas

Ketonggo rata-rata berusia 31-45 tahun ke atas, dengan berbagai profesi diantaranya petani/buruh tani (25\%), wiraswata/pedagang (40\%), sektor informal (10\%), ustadz/pekerja sosial keagamaan (10\%), PNS (5\%), lainnya (10\%). Kebanyakan pengunjung yakin bahwa dengan mendatangi dan ngalap berkah di Alas Ketonggo tersebut mereka akan mendapatkan berkah atau keberuntungan sesuai yang dihajatkan.

Mereka yang mengunjungi Alas Ketonggo pada umumnya telah dilandasi dengan niat dan tujuan yang didorong oleh kemauan batin yang mantap. Masing-masing mempunyai motivasi yang belum tentu sama. Secara umum, motivasi pengunjung ke Alas Ketonggo tersebut sesungguhnya hampir sama, yaitu seputar untuk

mendapat

keselamatan, kesehatan, keberkahan, kesembuhan, ungkapan syukur, kemudahan rizki, jodoh, dan nasib baik.

Kunjungan masyarakat ke Alas Ketonggo selalu disertai dengan tradisi dan ritual tertentu sesuai dengan kebiasaan masing-masing. Model ritual ini terkadang sangat mencolok berbeda antara satu orang dengan orang lain atau satu rombongan dengan rombongan lainnya. Semuanya tergantung pada kebiasaan secara turun temurun atau keyakinan yang pada pada masing-masing pihak. Selain itu, di Alas Ketonggo yang menjadi obyek penelitian, walaupun sejumlah bentuk ritual dilakukan sama tetapi ada hal-hal tertentu yang membuatnya berbeda, terutama karena ada ciri khusus situs Alas Ketonggo yang berbeda. Hal inilah yang mempengaruhi ekspresi masyarakat dalam melakukan 
berbagai acara dan ritual.

Banyak ritual yang merupakan warisan leluhur adat yang terwarisi secara turun temurun.

Secara umum bentukbentuk ritual pengunjung di Alas Ketonggo, diantaranya tabur kembang (nyekar), menaruh sesaji, membakar dupa, usap wajah/kepala dengan air sungai, mandi di sungai, Ngurisan/srakalan, dzikir dan tahlil, bertapa/menjalankan 'amalan', syukuran (makanmakan), mengisi kotak amal, minta doa juru kunci (wawancara dengan Marji 25 April 2013).

Ramainya

para pengunjung ke Alas Ketonggo tersebut menunjukkan bahwa masyarakat mempunyai kepercayaan khusus. Kepercayaan itu biasanya berpangkal dari keyakinan tentang kekeramatan (karâmah) dari pribadi yang dimakamkan. Seperti kata agama merupakan sebuah sistem kebudayaan, karena itu agama berpusat pada pikiran dan perasaan manusia yang selanjutnya dijadikan acuan melakukan tindakan, juga untuk menafsirkan realitas yang dihadapinya. Ada beberapa alasan dan hikmah penting yang dapat diambil dari Wisata Alas Ketonggo, yaitu: penegasan bahwa kematian hanyalah suatu proses menuju kehidupan baru yang lebih abadi, juga ada hubungan antara yang hidup dan yang meninggal masih dapat dilanjutkan meskipun polanya tidak sama seperti pola hubungan horizontal ketika manusia sama-sama masih hidup.

\section{Dampak Alas Ketonggo bagi} sosio-religi masyarakat Desa Babadan

Sebagai tempat wisata religi Alas Ketonggo tidak ramai dikunjungi banyak orang seperti wisata hiburan yang lain. Namun, Alas Ketonggo juga mempunyai pengunjung tetap dari luar daerah Ngawi bahkan dari Malaysia dan Singapura yang rutin tiap 
tahun berkunjung. Biasanya pengunjung lebih banyak datang pada bulan Suro dalam kalender Jawa. Letaknya yang strategis di pinggir hutan dan dialiri dua buah sungai, sehingga tempat ini sangat cocok untuk menentramkan hati (wawancara dengan Sri 25 April 2013).

Sejak dibuka untuk wisata religi tahun 1974, Alas Ketonggo ini juga sangat berpengaruh terhadap sosioreligi masyarakat Desa Babadan. Masyarakat Desa Babadan sebagian besar beragama Islam, banyak berdiri masjid dan mushola di sekitar desa. Namun, dalam kehidupan kesehariannya agama Islam ini dipengaruhi oleh unsur kebudayaan Jawa Alas Ketonggo. Sebagai contoh, Masyarakat Desa Babadan sangat menjaga adat yang telah ditetapkan di Alas Ketonggo. Bila ada penduduk yang akan mempunyai hajat, seperti mengislamkan putranya (aqikahan dan khitanan), upacara pernikahan atau yang lainnya, harus melaksanakan acara sedekah yang bertempat di Alas Ketonggo yang dipimpin oleh juru kunci Alas Ketonggo sendiri (wawancara dengan Marji 25 april 2013).

Kehidupan

beragama masyarakat Desa Babadan yang terletak di perbatasan Jawa Timur dan Jawa Tengah suasana budaya Jawa sangat terasa di Desa Babadan, dalam hal kegiatan agama Islam misalnya, suasananya sangat di pengaruhi oleh aspek budaya dan sosial Jawa. Hal ini terlihat dari dipakainya kalender Jawa/Islam, masih adanya budaya nyadran (bersih desa), slametan, tahlilan, mithoni, dan lainnya, yang keseluruhan merefleksikan sisi-sisi akulturasi budaya Islam dan Jawa.

Selain sebagai ungkapan rasa syukur kepada Tuhan Yang Maha Esa, Wisata Alas Ketonggo juga diyakini oleh masyarakat setempat sebagai ajang untuk 


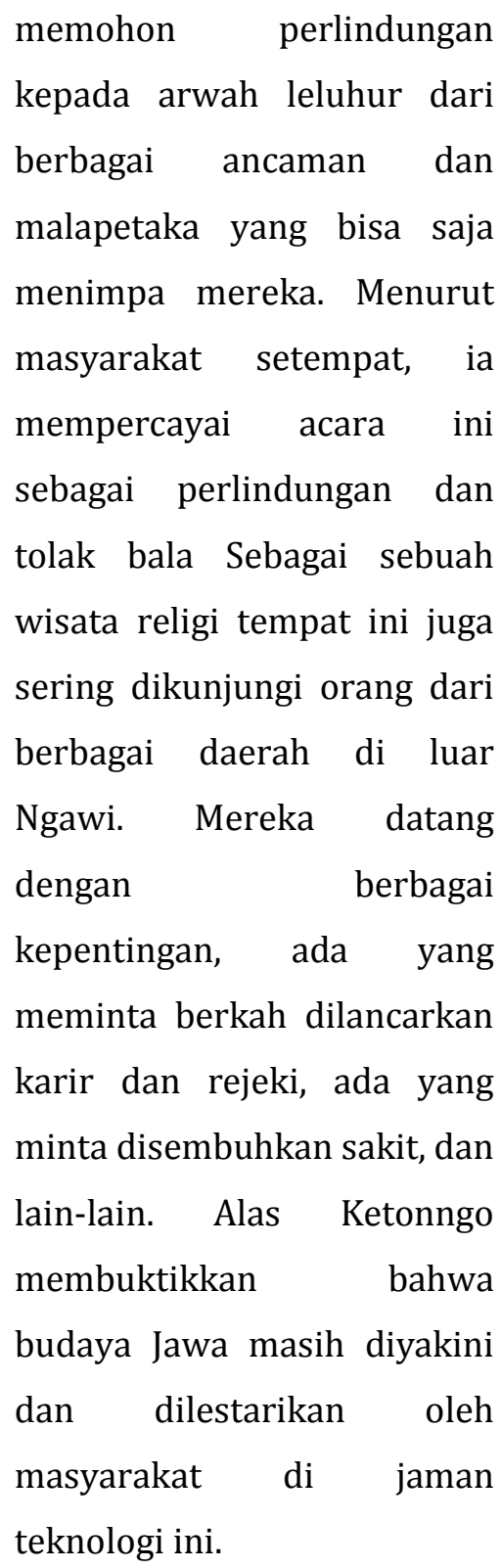

Kepercayaan

masyarakat bahwa Alas

Ketonggo adalah tempat yang

dikeramatkan atau disucikan, sangat terasa saat memasuki Alas Ketonggo yang sunyi dan sepi, serta pekat aroma bunga. Penduduk sekitar tidak sembarangan pergi ke
Alas Ketonggo hanya yang berkepentingan tertentu. Pengunjung di Alas Ketonggo juga tidak selalu ramai, hanya pada bulan Sura diadakan pentas budaya Jawa wayang kulit. Biasanya penyelenggara adalah masyarakat yang merasa keinginannya terkabul berkah di Alas Ketonggo (wawancara dengan Surawan 24 April 2013).

Dapat difahami bahwa sebagai sebuah bagian dari kepercayaan yang dianut oleh masyarakat dan diwujudkan dalam riual adat, Alas Ketonngo diyakini bisa memberikan kekuatan moral bagi masyarakat untuk berlindung kepada Sang Penguasa dari berbagai hal-hal yang tidak diinginkan. Masyarakat yang memegang erat nilai moral sosial dalam acara tersebut mempercayai bahwa apabila kegiatan itu tidak dilaksanakan, maka akan terjadi sesuatu yang buruk yang akan menimpa masyarakat (wawancara dengan Mustofa 23 Juni 2013). 


\begin{abstract}
Setiap keganjilan dan hal-hal yang dianggap tidak sesuai dengan keinginan dan kebetulan menimpanya selalu dikaitkan dengan Alas Ketonggo tersebut. Menurut kesaksian dari beberapa informan di Alas Ketonggo sering terjadi hal-hal aneh sebagai pertanda akan terjadi sesuatu hal, hingga sekarang kepercayaan ini masih diyakini masyarakat Desa Babadan (wawancara dengan Badriyah 23 Juni 2013).
\end{abstract}

Alas Ketonggo sangat diyakini masyarakat mempunyai pengaruh bagi ketentraman dan keamanan Desa Babadan. Jadi hingga sekarang sangat dijaga dan dilestarikan tempat tersebut, sesuai anjuran dari kepala Desa Babadan terdahulu. Selain menjaga adat, masyarakat juga ikut menjaga kelestarian hutan, dengan tidak menebang pohon sembarangan, dan ada kegiatan penghijauan yang diadakan pihak Perhutani. Selain itu, Alas Ketonggo juga dijadikan bumi perkemahan setiap peringatan Hari Pramuka (14 Agustus). Jadi bukan saja sebagai tempat wisata religi yang dianggap mistis, namun Alas Ketonggo juga dibuka untuk tempat kegiatan lain (wawancara dengan Surawan 24 April 2013).

\section{Pembahasan}

\section{A. Alas Ketonggo Sebagai Objek Wisata}

Alas Ketonggo merupakan sebuah hutan di Desa Babadan Kecamatan Paron Kabupaten Ngawi. Hutan ini sedikit berbeda fungsi dibanding hutan lain, tidak hanya lahan perhutani, namun hutan ini merupakan tempat wisata religi, yang dikenal masyarakat hingga luar daerah Kabupaten Ngawi. Tempat spiritual ini merupakan areal hutan jati milik Perhutani RKPH Kuncen dan Babadan yang berada di wilayah Desa Babadan, Kecamatan Paron, Kabupaten Ngawi. Berjarak sekitar $4 \mathrm{~km}$ dari jalan raya Kabupaten antara Ngawi-Jogorogo. Dari Ibukota 
Kabupaten berjarak $15 \mathrm{~km}$ dengan

waktu tempuh selama 15 menit.

Objek wisata adalah hal, perkara, orang yang menjadi pokok pembicaraan atau benda, hal, dan sebagainya yang dijadikan sasaran untuk diteliti, diperhatikan dan sebagainya dalam wisata (Tim Penyusun Kamus, 1991: 622). Alas Ketonggo ini bukan tempat pariwisata yang mempunyai fasilitas hiburan, namun Alas Ketonggo ini merupakan objek wisata budaya dengan daya tarik adat budaya Jawa, sekaligus juga merupakan objek wisata alam yang mempunyai daya tarik keindahan alam daerah perhutani.

Para pengunjung atau wisatawan tidak hanya dari wisatawan domestik, tetapi juga dari luar negeri. Menurut Juru Kunci Marji, tamu luar negeri yang pernah datang di Alas Ketonggo diantaranya Singapura, Malaysia dan Brunei sudah menjadi langganan berkunjung ke Alas Ketonggo setiap tahunnya. Dilihat dari jumlah pengunjungnya, tempat spiritual ini yang paling besar daripada tempat wisata lain di Kabupaten Ngawi. Terutama pada hari-hari tertentu di Bulan
Sura dalam kalender Jawa, yang dipercaya oleh masyarakat Jawa memiliki tuah dan berkah jumlah pengunjungnya bisa mencapai ribuan.

Dari keterangan Juru Kunci dan masyarakat sekitar, bahwa Alas Ketonggo memiliki sejarah panjang dengan masyarakat Jawa utamanya Hindu, Budha dan Islam. Sehingga sangat pantas situs Alas Ketonggo memiliki nilai tersendiri dalam budaya Jawa. Dijelaskan pula bahwa Alas Ketonggo mempunyai sekuel kisah dari Prabu Brawijaya V, yang melarikan diri dan singgah di Alas Ketonggo. Masa transisi seorang raja besar ini membuat aura Alas Ketonggo sangat mansyur di kalangan masyarakat Jawa. Faktanya di tempat ini disimpan pakaian keprabon dan benda-benda pusaka Prabu Brawijaya V. Dugaan lain, di sekitar Alas Ketonggo ini merupakan perkampungan permanen, terbukti banyak kubur kuno disekitar situs.

Sekarang Alas Ketonggo tidak hanya sebagai tempat kunjungan para spiritualis Jawa, namun sudah berkembang menjadi tempat pariwisata. Letaknya yang 
strategis dipinggir hutan dan dialiri dua buah sungai, tempat ini menjadi nyaman untuk menentramkan hati. Sehingga banyak pengunjung yang sekedar singgah saja tanpa ada tujuan tertentu. Di tempat ini pada saat tertentu juga seringkali diadakan pentas budaya Jawa, utamanya wayang kulit. Biasanya penyelenggara adalah masyarakat yang merasa keinginannya terkabul berkah di Alas Ketonggo. Ada beberapa tempat yang menjadi daya tarik Alas Ketonggo, ada banyak situs diantaranya Palenggahan Agung Srigati, Kali Tempuran, Sendang Derajat, Gua Teluk, Watu Dakon, Tugu Emas, dll. Keseluruhan tempat tersebut mempunyai makna filosofi yang berbeda, jadi pengungung harus menyesuaikan tempat dan tujuan sesuai arahan juru kunci. Ternyata di masa serba teknologi seperti ini budaya Jawa masih dilestarikan dan diyakini oleh masyarakat dari berbagai kalangan dan daerah.

B. Kepercayaan masyarakat Desa Babadan Kecamatan Paron Kabupaten Ngawi terhadap Alas Ketonggo
Wisata Alas Ketonggo merupakan salah satu tindakan simbol religi sebagai sisa peninggalan jaman animisme dan dinamisme. Sama halnya dengan pendapat Imam Budhi Santosa (2012:174) bahwa orang Jawa dikenal ramah, terbuka, sopan dan religius, ada bermacam agama dan kepercayaan yang sempat dianut oleh orang Jawa dan berpengaruh besar terhadap budaya dan pandangan hidupnya. Yaitu, kepercayaan pra-Hindu: animisme dan dinamisme, kemudian Hindu, Budha dan Islam. Pemberian sesaji pada tempat tertentu dan bau pekat dupa yang ada merupakan salah satu buktinya.

\section{Maksud}

diselenggarakannya sesaji ialah untuk mendukung kepercayaan mereka terhadap kekuatan makluk-makluk halus. Selain itu juga untuk meminta berkah dan lindungan dari penghuni tempat tersebut serta sebagi bukti penghormatan mereka. Selain itu, tujuan diadakannya upacara yakni merupakan suatu ajakan yang secara tidak langsung untuk menjaga lingkungan sekitar. 
Masyarakat Desa Babadan

Keinginan

luhur

mempunyai tradisi turun-

masyarakat

untuk

temurun, bila akan mempunyai

hajat harus syukuran atau

mengungkapkan rasa syukur ini

nyadran di Alas Ketonno. Tradisi

ini dilakukan demi mencapai

ketentraman hidup lahir batin,

dengan mengadakan upacara

tradisi ini, masyarakat Desa

Babadan telah memenuhi

kebutuhan spiritualnya.

Kehidupan rohani

mereka memang bersumber dari ajaran agama yang telah diberi hiasan budaya lokal. Oleh karena itu, orientasi kehidupan keberagamaan mereka senantiasa memperhatikan nilainilai luhur yang telah diwariskan oleh nenek moyangnya. Sebagai sebuah ritual agama Alas Ketonggo adalah sebuah ekspresi sejarah yang juga tidak bisa telepas dari nilai-nilai religiusitas. Jadi sebagai sebuah warisan budaya, acara ini juga menyimpan makna tersirat sebagai sarana yang berfungsi sebagai media komunikasi agama dan spiritual. Hal ini sebagai bentuk rasa syukur masyarakat akan berbagai anugrah yang diperoleh selama hidupnya. terwujud dalam beberapa ritual adat yang diselenggarakan pada acara nyadran, antara lain prosesi pembuatan berbagai makanan khas yang menunjukkan rasa syukur masyarakat akan potensi alam yang dianugrahkan oleh Sang Penguasa alam semsesta. Selain sebagai ungkapan rasa syukur kepada Tuhan Yang Maha Esa, Wisata Alas Ketonggo juga diyakini oleh masyarakat setempat sebagai ajang untuk memohon perlindungan kepada arwah leluhur dari berbagai ancaman dan malapetaka yang bisa saja menimpa mereka.

Menurut Imam Budhi Santosa (2012: 241), bahwa penduduk asli di Jawa telah mempunyai sistem religi (kepercayaan) yang dianut dan diamalkan dalam kehidupan kesehariannya. Inti dari religiositas ini adalah, mereka percaya mengenai adanya roh atau jiwa pada manusia, hewan, tumbuhan, dan benda-benda lain di dunia. Disamping itu, mereka juga percaya akan adanya roh 
adikodrati, yang paling tinggi (paling berkuasa) mengatur kehidupan manusia. Masyarakat setempat juga mempercayai acara ini sebagai perlindungan dan tolak bala Sebagai sebuah wisata religi tempat ini juga sering dikunjungi orang dari berbagai daerah di luar Ngawi. Mereka datang dengan berbagai kepentingan, ada yang meminta berkah dilancarkan karir dan rejeki, ada yang minta disembuhkan sakit, dan lain-lain. Alas Ketonggo membuktikkan bahwa budaya Jawa masih diyakini dan dilestarikan oleh masyarakat di jaman teknologi ini.

Fenomena ini sampai sekarang acapkali terlihat dalam kehidupan keberagamaan kaum awam. Umumnya mereka selalu menghubungkan keyakinan agama dengan kejadian-kejadian supranatural dari orang-orang yang mereka pandang "suci". Magisme itu timbul karena adanya harapan seseorang akan terjadinya hal-hal luar biasa untuk dirinya atau orang yang dikehendaki, sebagai cara yang tepat untuk memperoleh suatu manfaat semisal kesembuhan, keamanan, kekayaan, dan kekuatan.

Kepercayaan tentang mukjizat atau karâmah sebab keduanya diakui adanya dalam agama. Menurut Islam, mukjizat hanyalah terjadi pada diri Nabi, sedangkan karomah hanya terjadi pada wali atau orangorang khusus. Di sinilah persoalan problematika keyakinan terhadap kekuatan supra-natural itu muncul. Dalam banyak fakta, masyarakat melihat bahwa orang-orang tertentu dari kalangan mereka dipandang memiliki suatu kelebihan, baik dalam hal penyembuhan atau kemustajabahan do'anya. Maka ketika tokoh-tokoh ini meninggal, makam atau petilasannya selalu ramai dikunjungi orang dari waktu ke waktu. Keyakinan magis-kekeramatan seperti di atas juga mudah dijumpai pada masyarakat Babadan.

Keyakinan keimanan para pengunjung dan masyarakat Desa Babadan masih ambivalen, campur-aduk, dan tidak murni. Satu sisi mereka menyatakan ketauhidannya secara mutlak 
akan tetapi di sisi lain mereka menyimpan kepercayaankepercayaan tertentu terhadap makam-makam yang dianggap keramat tersebut untuk keberhasilan maksud dan tujuan yang mereka inginkan. Persoalannya adalah bila mereka melakukan kunjungan ke wisata religi kuno yang diyakini masyarakat luas sebagai tempattempat keramat, maka niatan mereka bisa jadi tetap berada pada garis yang lurus, atau mungkin juga telah terjadi penyimpangan sehingga dapat membahayakan kemurnian tauhid mereka karena dalam ritualnya terjadi tumpang tindih antara hal-hal yang berasal dari religi dan dari tradisi.

\section{Dampak Wisata Alas Ketonggo} terhadap Sosio Religi Masyarakat

\section{Desa Babadan}

$$
\begin{aligned}
& \text { Pariwisata bagi sebagian } \\
& \text { daerah dijadikan suatu sarana } \\
& \text { penambahan dan penunjang } \\
& \text { pendapatan/devisa suatu daerah, } \\
& \text { namun ada hal lebih penting } \\
& \text { bahwa pariwisata merupakan } \\
& \text { salah satu penyebab adanya } \\
& \text { perubahan sosial yang terjadi di } \\
& \text { masyarakat yang disebabkan oleh }
\end{aligned}
$$

faktor dari luar. Menurut pendapat Kodhyat (1996: 10) bahwa, kegiatan wisata dapat menimbulkan berbagai dampak positif dan negatif di berbagai bidang kehidupan, yaitu ekonomi, pendidikan, sosial budaya, sikap dan jati diri. Meskipun hanya wisata religi, tapi Alas Ketonggo banyak dikunjungi masyarakat dari luar daerah yang memungkinkan adanya perubahan sosial yang terjadi. Sebagai wisata religi perubahan lebih dominan terjadi dalam apek sosio religi masyarakat yaitu:

1. Menanamkan Nilai Positif Kepercayaan Jawa

Sejarah perkembangan religi orang Jawa telah dimulai sejak jaman prasejarah. Pada waktu itu nenek moyang orang Jawa sudah beranggapan bahwa semua benda yang ada di sekelilingnya itu bernyawa. Semua yang bergerak dianggap hidup dan mempunyai kekuatan gaib atau mempunyai roh yang berwatak baik maupun jahat. Dengan dasar anggapan demikian mereka membayangkan dalam anganangan mereka bahwa 
disamping segala roh yang ada tentulah ada roh yang paling berkuasa dan lebih kuat dari manusia.

Untuk menghindarkan ganguan dari roh itu maka mereka memujamujanya dengan jalan mengadakan upacara.

\begin{tabular}{lrr}
\multicolumn{2}{c}{ Pemujaan } & kepada \\
arwah nenek & moyang \\
merupakan agama & mereka \\
yang pertama. & Mereka
\end{tabular}
meminta berkah dan petunjuk dari arwah nenek moyang tersebut. Sarana yang ditempuh untuk mendatangkan arwah nenek moyang ialah dengan cara mengadakan upacara. Sisa upacara religius seperti tersebut diatas sampai sekarang masih ada dalam kehidupan masyarakat Jawa Khususnya masyarakat Desa Babadan, yaitu Wisata Religi Alas Ketonggo yang hingga saat ini masih dilestarikan. Alas Ketonggo menjadi tempat upacara religi oleh masyarakat Desa Babadan, bila ada masyarakat yang akan mempunyai hajat harus mengadakan syukuran di Alas
Ketonggo yang dipimpin oleh Juru Kunci. Selain itu juga ada masyarakat dari luar daerah yang datang berkunjung untuk ngalap berkah, sehingga tempat ini menjadi wisata religi.

Pelaksanaan upacara di Alas Ketonggo sebagai bukti perwujudan dari nilai kepercayaan Jawa yang dianut oleh masyarakat, pada tiap upacara memiliki sifat magis dan religious, karena merupakan warisan leluhur yang dalam pandangan masyarakat menduduki posisi setara dengan dewa. Hal ini sesuai dengan pendapat Koenjtaraningrat (2009: 295297), bahwa suatu sistem religi selalu mempunyai unsur-unsur yang penting untuk memelihara agama serta para penganutnya salah satunya adalah upacara keagamaan. Upacara ini dilaksanakan demi memperoleh berkah dan kemurahan.

Kepercayaan

masyarakat tersebut diatas dilandasi karena adanya keyakinan yang dimiliki oleh 
masyarakat setempat. Sebagai

manifestasi dari agama dan

kepercayaan yang dianut oleh

masyarakat, upacara juga

tentunya memiliki fungsi sosial

bagi masyarakat sebagai

pengokoh kekuatan moral.

Setiap masyarakat bisa tetap

eksis dan survive karena sikap

kooperatif dari anggota-

anggotanya. Sifat kooperatif

antarwarga masyarakat itu

sendiri diperoleh melalui jalur

sosialisasi dan agama adalah

sumber utama proses

sosialisasi yang dimaksud.

Agama berperan memberikan

sokongan psikologis. Agama

selain membantu orang lain

dari kebingungan dunia dan

menawarkan jawaban tentang

berbagai permasalahan, juga

memberikan kekuatan moral.

2. Penggabungan Kepercayaan

Animisme dan Dinamisme

Pada masyarakat yang

sudah maju, kepercayaan yang

dianut bukan lagi dinamisme

ataupun animisme tetapi

kepercayaan monoteisme.

Para penganut monoteisme

beranggapan bahwa hanya

ada satu tuhan bagi mereka.
Tuhan tersebut mencipta, memelihara dan kemudian menghancurkan alam semesta ini. Dialah penguasa tunggal yang berada dan berasal dari luar alam semesta ini.

Masyarakat Desa

Babadan sudah termasuk ke dalam penganut kepercayaan monoteisme namun hanya secara teoritis. Mereka mempercayai bahwa Tuhan itu Esa dalam teori, tetapi di dalam praktek mereka mempercayai lebih dari satu Tuhan. Menurut Durkheim dalam Imam Muhni (1994: 128) bahwa religi merupakan sesuatu yang tidak dapat dielakkan dalam kehidupan masyarakat. Pembagian dunia dalam yang sakral dan yang profane merupakan ciri khas pemikiran religius. Hal-hal yang sakral bukan diartikan dewa-dewa atau roh-roh, melainkan apa saja yang dapat menjadi sakral atau dijadikan sakral.

Masyarakat Desa Babadan beranggapan bahwa mereka menempati dunia ini berrsama-sama dengan begitu 
banyak roh. Selain itu terdapat

satu keterkaitan proses gerakan alam dengan gerakan ro-roh tersebut. Mereka juga mempercayai bahwa manusia memiliki jiwa yang bisa meninggalkan tempatnya dan memasuki makhluk lain. Animisme merupakan suatu pemikiran yang tidak hanya memberikan penjelasan atau suatu fenomena saja, tetapi memungkinkan manusia memahami keseluruhan dunia.

Sedangkan dari sisi dinamisme mereka percaya bahwa benda atau materi memiliki kesamaan sifat dengan manusia. Sebagai contoh, api memiliki sifat yang sama dengan manusia. Api memiliki kekuatan untuk membunuh atau melenyapkan apapun dengan panasnya. Sebagaimana manusia mampu membunuh dengan kekuatan tangannya. Karena itulah api dipercaya memiliki roh, sama halnya dengan keberadaan beberapa tempat petilasan $\mathrm{di}$ Alas Ketonggo. Maka dari itulah perlu diadakannya suatu penghormatan. Proses tersebut dilakukan agar tidak terjadi sesuatu yang tidak diinginkan.

\section{Daftar Pustaka}

Imam Muhni.1994.Moral dan Religi.Yogyakarta:Kanisius

Budiono Herusatoto.2008.Simbolisme Jawa.Yoggkd fittbagyndan04.Metode Penelitian Dalam Penelitian d Bustanuddin Agus.2007.Agama Dalam Kehidupan Mandlssialjakarta:PT Raja Grafindo Persada. Koentjaraningrat.1997.Manusia dan Kebudayaan di Indor

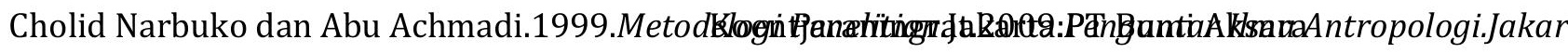

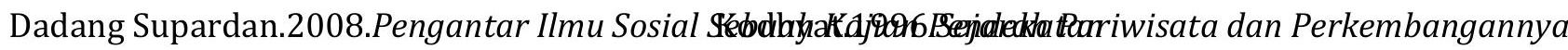
Struktural.Jakarta:PT Bumi Aksara Gramedia Widiasarana Indonesia

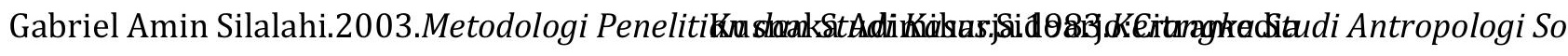
Gamal Suwantoro.2004.Dasar-dasar Pariwisata.Yogyakdletar.badklgunan.Bandung:Tarsito

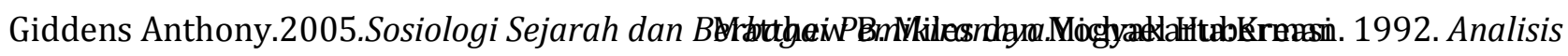
Wacana Tentang Metode-Metode Baru. Terjemahan Oleh

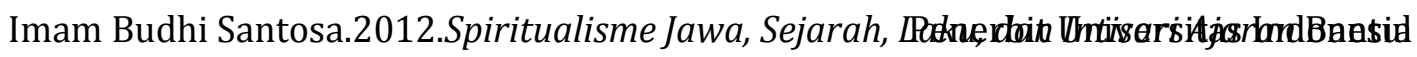
Yogyakarta:Memayu Publishing. Moh Nazir.2011.Metode Penelitian.Bogor:Ghalia Indones 


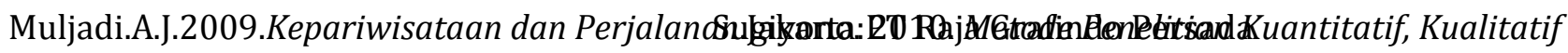

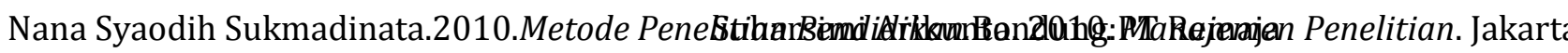
Rosdakarya Suharsimi Arikunto. 2010. Prosedur Penelitian: Suatu Per Nurul Zuriah.2006.Metodologi Penelitian Sosial dan PeRididkka6i|atlaarta:Bumi Aksara

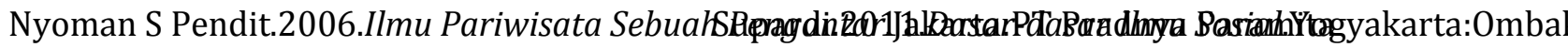

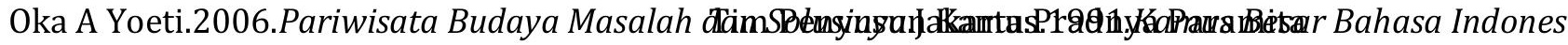
Profil Desa Babadan tahun 2012 Yin K Robert.2008.Studi Kasus Desain dan Metode.Jakarta Purwadi.2005.Upacara Tradisional Jawa.Yogyakarta:Pustaka Pelajar Saifuddin Azwar.2004.Metode Penelitian.Yogyakarta:Pustaka Pelajar Sotopo H B.2006.Metodologi Penelitian Kualitatif.Surakarta:Universitas Sebelas Maret 